Кондратюк В. М.

UDC 639.2.09:[591.11:597.552.56]:636.085.55

\title{
HEMATOLOGICAL AND BIOCHEMICAL INDICATORS OF RAINBOW TROUT BLOOD DEPENDING ON LYSIN AND METHIONINE LEVELS IN COMBINED FEED
}

\author{
V. KONDRATIUK, candidate of agricultural Sciences, Associate Professor, \\ https://orcid.org/0000-0002-4246-2639
}

\section{National University of Life and Environmental Sciences of Ukraine}

E-mail: vadkondratyk@ukr.net

https://doi.org/10.31548/dopovidi2021.03.007

Abstract. The effect of use of complete feed with different lysine and methionine levels on the hematological and biochemical indicators of rainbow trout blood is studied in the article. The aim of the experiment was to establish the effect of different levels of amino acid nutrition of commercial rainbow trout on hematological and biochemical indicators of its blood. For this purpose, five experimental groups were formed by the analog method. The study lasted 210 days and was divided into two periods: equalizing (10 days) and basic (200 days). In the equalizing period, the trial fish consumed feed of the control group. In the basic period of the experiment, the level of lysine and methionine in the production feed ranged from 2.5 to $2.9 \%$ and from 0.8 to $1.0 \%$, respectively.

It was found that the different content of lysine and methionine in the diets of twoyear-old rainbow trout did not cause significant changes in biochemical indicators of blood. The increase in the content of limiting amino acids in the combined feed of young rainbow trout caused slight deviations in hemoglobin content compared to control. The analysis of the obtained results revealed the highest content of erythrocytes $(1.28 \mathrm{~T} / \mathrm{l})$ in the blood of specimen of experimental group 5 , the level of amino acids in combined feeds was the lowest. Its highest content was found in the blood plasma of trout of experimental group 4, which received combined feed with a content of $2.8 \%$ lysine and $0.95 \%$ methionine. The concentration of total protein in the blood serum was almost the same in all experimental groups of commercial rainbow trout. It was found that different levels of amino acid nutrition of rainbow trout did not affect the dynamics of changes in the blood cell morphology differentials.

Key words: Commercial rainbow trout, fish feeding, combined feed, lysine, methionine, hematological indicators, blood cell morphology differentials, biochemical indicators of blood

Background of the article and analysis of recent studies and publications. Observance of optimal conditions of rearing and well-balanced feeding are important factors influencing the intensity of fish growth. Rational use of nutrients of combined feed allows to obtain high-quality marketable products in a short time. Hematological and biochemical indicators of rainbow trout blood are important for assessing the quality of feeding [1]. 
Кондратюк В. М.

Blood is a sensitive and informative indicator of the body state, responds quickly to changes of both exogenous and endogenous factors. The dynamics of biochemical indicators can serve as a marker of the body state of fish, characterize the quality of feeding. Biochemical studies of blood serum are important for characterization of the overall condition of the body of twoyear-old rainbow trout, which make it possible to obtain additional data on the physiological state of fish. Blood proteins regulate colloid-osmotic pressure in the body, maintain a $\mathrm{pH}$ balance, perform a transport function. Plasma proteins can serve as a reserve of amino acids [2-4].

Thus, the study of the influence of different amino acid nutrition of commercial rainbow trout on hematological and biochemical indicators is necessary to determine the need of fish for lysine and methionine in order to ensure the successful activity of cold-water fish farms in Ukraine.

\section{Materials and Methods of} Studies. Experimental studies on twoyear-old rainbow trout Oncorhynchus mykiss (Walbaum, 1792) were conducted in the farm "Shipot" of the Perechynsky district of the Zakarpatska Oblast.

The aim of the scientific and economic experiment was to establish the effect of different levels of amino acid nutrition of commercial rainbow trout on hematological and biochemical indicators of its blood.

For this purpose, five experimental groups were formed by the analog method (Table 1). In the equalizing period, the trial fish consumed combined feed of the control group, where lysine and methionine levels were the same. In the basic period, fish of all groups received a similar diet, except for the lysine and methionine level therein. The mentioned amino acids were added in one or another proportion, as provided by the flow diagram of the experiment.

\section{Flow Diagram of Scientific and Economic Experiment}

\begin{tabular}{|c|c|c|c|c|c|c|}
\hline \multirow{4}{*}{ Fish group } & \multirow{4}{*}{$\begin{array}{l}\text { Fish-holding } \\
\text { density } \\
\text { At the } \\
\text { beginning of } \\
\text { experiment, } \\
\text { specimens } / \mathrm{m}^{2}\end{array}$} & \multirow{4}{*}{$\begin{array}{l}\text { Average } \\
\text { weight at } \\
\text { the } \\
\text { beginning } \\
\text { of } \\
\text { experiment, } \\
\text { g }\end{array}$} & \multicolumn{4}{|c|}{ Periods of the experiment } \\
\hline & & & \multicolumn{2}{|c|}{$\begin{array}{l}\text { equalizing } \\
\text { (10 days) }\end{array}$} & \multicolumn{2}{|c|}{$\begin{array}{c}\text { basic } \\
\text { (200 days) }\end{array}$} \\
\hline & & & \multicolumn{4}{|c|}{ content in $1 \mathrm{~kg}$ combined feed, $\%$} \\
\hline & & & lysine & methionine & lysine & methionine \\
\hline 1- control & 50 & $53.9 \pm 3.17$ & \multirow{5}{*}{2.7} & \multirow{5}{*}{0.9} & 2.7 & 0.90 \\
\hline 2- experimental & 50 & $53.4 \pm 2.86$ & & & 2.5 & 0.80 \\
\hline 3- experimental & 50 & $54.2 \pm 3.74$ & & & 2.6 & 0.85 \\
\hline 4- experimental & 50 & $52.7 \pm 3.29$ & & & 2.8 & 0.95 \\
\hline 5- experimental & 50 & $54.0 \pm 3.06$ & & & 2.9 & 1.00 \\
\hline
\end{tabular}


Кондратюк В. М.

The nutrient density of

experimental production feed is shown

in table 2.

\section{Content in $1 \mathrm{~kg}$ of combined feed, $\%$}

\begin{tabular}{|l|c|c|c|c|c|}
\hline \multirow{2}{*}{ Indicator } & \multicolumn{5}{c|}{ Group } \\
\cline { 2 - 6 } & 1 & 2 & 3 & 4 & 5 \\
\hline Metabolic energy, MJ & 17.00 & 17.00 & 17.00 & 17.00 & 17.00 \\
\hline Crude protein & 48.00 & 48.00 & 48.00 & 48.00 & 48.00 \\
\hline Crude fat & 18.00 & 18.00 & 18.00 & 18.00 & 18.00 \\
\hline Crude fiber & 2.40 & 2.40 & 2.40 & 2.40 & 2.40 \\
\hline Calcium & 1.80 & 1.80 & 1.80 & 1.80 & 1.80 \\
\hline Total phosphorus & 1.20 & 1.20 & 1.20 & 1.20 & 1.20 \\
\hline Lysine & 2.70 & 2.50 & 2.60 & 2.80 & 2.90 \\
\hline Methionine & 0.90 & 0.80 & 0.85 & 0.95 & 1.00 \\
\hline Vitamin A, thous. IU & 10 & 10 & 10 & 10 & 10 \\
\hline Vitamin $\mathrm{D}_{3}$, thous. IU & 3 & 3 & 3 & 3 & 3 \\
\hline Vitamin E, mg & 200 & 200 & 200 & 200 & 200 \\
\hline
\end{tabular}

Feeding of rainbow trout in the study period was performed 4-6 times a day, in the day time at regular intervals. The required amount of feed was calculated according to the indicators of individual fish weight and ambient temperature at the time of feeding.

Weighing of the experimental trout was performed every 10 days on electronic scales in a calibrated container with water, with an accuracy of $0.1 \mathrm{~g}$. Rearing of commercial two-year-old ones was performed in ponds with an area of $100 \mathrm{~m}^{2}$ at a fish-holding density of 50 specimens $/ \mathrm{m}^{2}$ and a water level of $1 \mathrm{~m}$. The total number of trout in experimental studies was 25 thousand specimens. The housing conditions of the experimental fish met the regulatory requirements in salmon farming [5-6].

Blood samples were taken from the heart using an injection needle inserted from the abdomen side along the sagittal line between the pectoral fins. Heparin was used as an anticoagulant.

The concentration of erythrocytes was determined by tube method using a storage solution, a microscope and a Gorjaev's chamber, leukocytes were determined by an indirect method on a blood film, hemoglobin was determined by a hemoglobin cyanide method on a spectrometer. In addition, total protein in the blood serum was determined with a refractometer [7-8].

The indicators of constructive metabolism, namely: Glucose in the blood of fish was determined according to the method of I. P. Kondrakhin et al. [8]. The method principle is based on the ability of glucose oxidase, oxidizing, to form a complex compound that turns the solution pink. The color intensity of the solution is proportional to the glucose 
Кондратюк В. М.

content in the sample. The concentration of glucose in the blood was calculated by a standard solution in mmol/l. The content of total protein in the blood plasma of fish was determined using reagent kits from Lachema (Czech Republic) and standard solutions of substrates.

The research results were processed according to the method of variation statistics [9] using the software
STATISTICA 7.0. and MS Excel with the use of built-in statistical functions.

Research results and their Discussion. The results of performed hematological studies also indicate that the different content of lysine and methionine in the diets of two-year-old rainbow trout does not cause significant changes in the morphological composition and biochemical indicators of the blood (Table 3).

\section{Hematological Indicators of Two-Year-Old Rainbow Trout, $n=5$}

\begin{tabular}{|l|c|c|c|c|c|}
\hline \multirow{2}{*}{ Indicator } & \multicolumn{5}{c|}{ Groups } \\
\cline { 2 - 6 } & 1 & 2 & 3 & 4 & 5 \\
\hline Erythrocytes, T/1 & $1.18 \pm 0.01$ & $1.21 \pm 0.06$ & $1.25 \pm 0.04$ & $1.19 \pm 0.05$ & $1.28 \pm 0.09$ \\
\hline Hemoglobin, g/l & $114 \pm 3.25$ & $116 \pm 4.01$ & $110 \pm 3.93$ & $124 \pm 2.87 *$ & $121 \pm 3.05$ \\
\hline Leukocytes, g/l & $22.1 \pm 0.9$ & $22.6 \pm 0.66$ & $22.8 \pm 0.75$ & $24.6 \pm 0.93$ & $23.9 \pm 0.91$ \\
\hline Phagocytic activity, \% & $43.2 \pm 2.01$ & $45.6 \pm 3.12$ & $46.3 \pm 2.85$ & $46.8 \pm 2.71$ & $45.9 \pm 2.03$ \\
\hline
\end{tabular}

$* \mathrm{p}<0.05$ compared with group 1

However, it was found that the fish from experimental group 2 and 3 have a slightly increased content of erythrocytes in the blood from $1.21 \mathrm{~T} / \mathrm{l}$ to $1.25 \mathrm{~T} / \mathrm{l}$, compared with analogues of the control group.

The use of combined feed with lysine and methionine levels of 2.8 and $0.95 \%$, respectively, in feeding of experimental fish led to a decrease in the number of erythrocytes in the blood. Thus, in the blood of trout from experimental group 4 it was $1.19 \mathrm{~T} / 1$, which is $1.7-5.0 \%$ less compared to similar indicators of fish from experimental groups 2 and 3.
A similar consistent pattern was also observed for the level of hemoglobin in the blood plasma of fish. Thus, its highest content was found in the blood plasma of trout from experimental group 4. The increase in the content of limiting amino acids in the combined feed of young rainbow trout caused slight deviations in hemoglobin content compared to control. Thus, the lowest level of hemoglobin $(110 \mathrm{~g} / \mathrm{l})$ was found in the blood of fish from experimental group 3, in the combined feed of which the lysine level was $2.6 \%$ and methionine level $-0.85 \%$.

Our studies also found that increasing the levels of amino acid 
Кондратюк В. М.

nutrition of two-year-old rainbow trout did not significantly affect the concentration of leukocytes, although it should be noted its slight positive effect on their number in fish from experimental groups 4 and 5 .

Therefore, the use of combined grower feed in feeding of commercial rainbow trout with different content of lysine and methionine did not significantly affect the morphological indicators of the blood.

Recently, great importance is given to the study of the interior indicators of fish as effective tests, which can be judged at an early age on their breeding and productive value. Among them, blood enzymes are of particular interest because they characterize the intensity of metabolic processes in fish body.

The results of our studies (Table 4) indicate that different levels of limiting amino acids (lysine and methionine) in the diets of two-year-old rainbow trout during the period of their rearing do not significantly affect the biochemical composition of the blood.

4. Biochemical profile of blood of experimental groups of rainbow trout, $n=5$

\begin{tabular}{|l|c|c|c|c|c|}
\hline \multirow{2}{*}{ Indicator } & \multicolumn{5}{c|}{ Groups } \\
\cline { 2 - 6 } & 1 & 2 & 3 & 4 & 5 \\
\hline Total protein, g/l & $68.3 \pm 2.03$ & $67.6 \pm 1.96$ & $68.8 \pm 1.88$ & $71.2 \pm 2.13$ & $70.8 \pm 2.44$ \\
\hline Albumins, g/l & $26.2 \pm 1.05$ & $25.4 \pm 0.96$ & $26.1 \pm 0.98$ & $27.12 \pm 1.11$ & $27.03 \pm 1.03$ \\
\hline Globulins, g/l: & $37.8 \pm 1.44$ & $36.2 \pm 1.36$ & $36.8 \pm 1.33$ & $39.1 \pm 1.59$ & $38.4 \pm 1.73$ \\
\hline$\alpha$-globulins & $13.01 \pm 0.99$ & $13.91 \pm 1.01$ & $13.44 \pm 0.66$ & $13.88 \pm 0.79$ & $13.96 \pm 0.88$ \\
\hline$\beta$ - globulins & $13.93 \pm 1.01$ & $14.02 \pm 1.11$ & $14.11 \pm 0.96$ & $14.75 \pm 1.15$ & $14.06 \pm 1.21$ \\
\hline$\gamma$-globulins & $10.86 \pm 0.77$ & $8.27 \pm 0.96$ & $9.25 \pm 0.79$ & $10.47 \pm 1.03$ & $10.38 \pm 0.96$ \\
\hline Albumin-globulin ratio & $0.66 \pm 0.02$ & $0.58 \pm 0.01$ & $0.61 \pm 0.02$ & $0.68 \pm 0.03$ & $0.71 \pm 0.03$ \\
\hline $\begin{array}{l}\text { Alanine aminotransferase, } \\
\text { U/L }\end{array}$ & $53.2 \pm 1.71$ & $52.8 \pm 1.75$ & $53.9 \pm 1.83$ & $58.6 \pm 1.58^{*}$ & $58.3 \pm 1,28^{*}$ \\
\hline $\begin{array}{l}\text { Aspartate } \\
\text { aminotransferase,U/L }\end{array}$ & $84.6 \pm 2.01$ & $81.8 \pm 2.12$ & $83.6 \pm 2.43$ & $89.1 \pm 2.19$ & $88.4 \pm 2.58$ \\
\hline Glucose, mmol/1 & $4.01 \pm 0.66$ & $3.92 \pm 0.71$ & $4.11 \pm 0.83$ & $4.32 \pm 0.74$ & $4.30 \pm 0.52$ \\
\hline Carotin, mg\% & $0.54 \pm 0.03$ & $0.51 \pm 0.01$ & $0.56 \pm 0.02$ & $0.63 \pm 0.03$ & $0.61 \pm 0.01$ \\
\hline Total calcium, mmol/1 & $2.6 \pm 0.44$ & $2.4 \pm 0.31$ & $2.7 \pm 0.71$ & $2.8 \pm 0.48$ & $2.7 \pm 0.33$ \\
\hline $\begin{array}{l}\text { Inorganic phosphorus, } \\
\text { mmol/l }\end{array}$ & $3.3 \pm 0.51$ & $3.1 \pm 0.28$ & $3.4 \pm 0.52$ & $3.6 \pm 0.58$ & $3.4 \pm 0.69$ \\
\hline Iron, mmol/1 & $26.2 \pm 1.03$ & $25.8 \pm 1.66$ & $25.9 \pm 1.81$ & $27.1 \pm 1.92$ & $26.9 \pm 1.84$ \\
\hline
\end{tabular}

$* \mathrm{p}<0.05$ compared with group 1

In order to characterize the general state of the body of two-year-old rainbow trout, we conducted biochemical studies of blood serum.
The concentration of total protein in the blood serum was almost the same in all experimental groups of commercial trout. However, it was noted that 
Кондратюк В. М.

increase in lysine and methionine levels in the combined feed of fish (experimental groups 4 and 5) contributed to a slight increase in the content of total protein in the blood serum.

The increased content of glucose in the blood of fish from experimental groups 4 and 5 attests the activity of metabolic processes in the body of trout, and as consequence - the balance of limiting amino acids in combined feed. Its highest content $(4.32 \mathrm{mmol} / \mathrm{l})$ was in the blood of trout from experimental group 4, the combined feed of which contained $2.8 \%$ lysine and $0.95 \%$ methionine.

However, it was found that the content of globulins in the blood of fish increases up to $39.1 \mathrm{~g} / \mathrm{l}$ compared with analogues of the control group (37.8 g/l) with increasing the level of lysine and methionine in the diet of rainbow trout. The similar consistent pattern was also observed for the content of albumins in the blood plasma. Thus, the highest content of albumins was found in the blood plasma of fish from group 4, which received complete feed with the increased level of lysine by $0.1 \%$ and of methionine by $0.05 \%$.

Therefore, the use of combined feed in feeding of rainbow trout with different content of lysine and methionine did not significantly affect the morphological and biochemical indicators of the blood.

The similar consistent pattern was also established in the assessment of white blood indicators of two-year-old trout (Table 5).

Moreover, it was found that different levels of amino acid nutrition of rainbow trout did not affect the dynamics of changes in the blood cell morphology differentials. It was found that the increase in lysine and methionine levels in combined feed fed to two-year-old trout was accompanied by a slight increase in the count of white blood cells, lymphocytes and monocytes in their blood.

\section{Dynamic pattern of the differential leukocyte count and content of total} lipids in the blood of two-year-old trout, $n=5$

\begin{tabular}{|l|c|c|c|c|c|}
\hline \multirow{2}{*}{\multicolumn{1}{c|}{ Indicator }} & \multicolumn{5}{c|}{ Groups } \\
\cline { 2 - 6 } & 1 & 2 & 3 & 4 & 5 \\
\hline Leukocytes, g/l & $22.1 \pm 0.9$ & $22.6 \pm 0.66$ & $22.8 \pm 0.75$ & $25.1 \pm 0.93 *$ & $23.9 \pm 0.91$ \\
\hline Neurofils, \% & $18.3 \pm 1.31$ & $17.9 \pm 1.12$ & $18.1 \pm 1.32$ & $18.6 \pm 1.35$ & $18.4 \pm 1.44$ \\
\hline Polymorphonuclear, \% & $3.8 \pm 0.66$ & $3.7 \pm 0.68$ & $3.9 \pm 0.52$ & $3.9 \pm 0.87$ & $3.8 \pm 0.79$ \\
\hline Lymphocytes, \% & $62.1 \pm 2.12$ & $60.8 \pm 2.31$ & $61.9 \pm 2.18$ & $62.4 \pm 2.36$ & $62.6 \pm 2.21$ \\
\hline Monocytes, \% & $17.9 \pm 1.08$ & $17.6 \pm 1.11$ & $17.8 \pm 1.09$ & $18.1 \pm 1.23$ & $18.3 \pm 1.31$ \\
\hline Total lipids, mmol/1 & $4.3 \pm 0.23$ & $4.2 \pm 0.32$ & $4.3 \pm 0.41$ & $4.4 \pm 0.36$ & $4.5 \pm 0.47$ \\
\hline
\end{tabular}

${ }^{*} \mathrm{p}<0.05$ compared with group 1 
Кондратюк В. М.

In addition, the level of total lipids remained unchanged and was $4.3 \mathrm{mmol} / 1$ in the blood of fish of the control group, and in the blood of the experimental groups, this indicator was in the range of 4.2-4.5 mmol/1.

\section{Conclusions}

1. It is proved that the content of erythrocytes in the blood increases from $1.21 \mathrm{~T} / 1$ to $1.25 \mathrm{~T} / 1$ with an increase of the lysine level up to 2.5 and $2.6 \%$ and the methionine level up to $0.8 \%$ and $0.85 \%$ in the diet of fish.

2. The lowest level of hemoglobin $(110 \mathrm{~g} / \mathrm{l})$ was found in the blood of fish from experimental group 3, in the combined feed of which the lysine level was $2.6 \%$ and the methionine level was $0.85 \%$.

3. It was found that the content of globulins in the blood of fish increases

\section{Reference}

1. Karabulut H. A., Yandi I., Aras N. M. (2010). Effects of different feed and temperature conditions on growth, meat yield, survival rate, feed conversion ratio and condition factor in rainbow trout (Oncorhynchus mykiss) fingerlings. Journal of Animal and Veterinary Advances. 9 (22), P. $2818 \quad-\quad 2823.2$ doi: 10.3923/javaa.2010.2818.2823.

2. Khan K., Rodrigues A., Cleber M. (2019). Dietary protein quality and proper protein to energy ratios: a bioeconomic approach in aquaculture feeding practices. Latin American Journal of Aquatic Research. 47(2), P. 232-239 doi:10.3856/vol47-issue2fulltext-3/.

3. Sherman I.M., Hrynzhevskyi M.V., Zheltov Yu.O. (2002). Naukove obhruntuvannia ratsionalnoi hodivli ryb: uchebnoe posobye. Vyshcha osvita. $128 \mathrm{p}$.

4. Mahmud S., Chakraborty C., Das M. (1996). Performance of rainbow trout up to $39.1 \mathrm{~g} / \mathrm{l}$ compared with analogues of the control group (37.8 g/l) with increasing the level of lysine and methionine in the diet of rainbow trout.

4. The highest content of albumins was found in the blood plasma of fish from group 4, which received complete feed with the increased level of lysine by $0.1 \%$ and of methionine by $0.05 \%$.

5. It was found that the increase in lysine and methionine levels in combined feed affected the increase in the count of white blood cells, lymphocytes and monocytes in their blood. Besides the level of total lipids was $4.3 \mathrm{mmol} / \mathrm{l}$ in the blood of fish of the control group, and in the blood of the experimental groups, this indicator was in the range of $4.2-4.5 \mathrm{mmol} / \mathrm{l}$.

(Oncorhynchus mykiss) fed on different dietary protein with fixed energy ratio AsianAustralasian Journal of Animal Sciences. № 9 (1), P. 31-35.

5. Kanidev A.N. Gamygin E.A. (1987). Progressivnye metody kormleniya raduzhnoj fore. Tr. VNIRO, Sadkovoe vyrashivanie foreli, 1977, t. 76, P. 109-116.

6. SOU-05.01-37-385 (2006). Voda rybohospodarskykh pidpryiemstv. Zahalni vymohy ta normy.

7. Vlizlo V.V.., Fedoruk R.S.., Ratych I.B. (2012). Laboratorni metody doslidzhen y biolohii tvarynnytstvi ta veterynarnii medytsyni dovidnyk. Lviv, s. 764

8. Kondrakhin, A. V. Arkhipov, V. I. Levchenko (2004). Metody veterinarnoj klinicheskoj laboratornoj diagnostiki: spravochni, Moskow, s.520.

9. Plokhynskyi N. A. (1969). Rukovodstvo po byometryy dlia zootekhnykov. M. Kolos. 246. 
Кондратюк В. М.

\section{ГЕМАТОЛОГІЧНІ ТА БІОХІМІЧНІ ПОКАЗНИКИ КРОВІ РАЙДУЖНОЇ ФОРЕЛІ ЗАЛЕЖНО ВІД РІВНІВ ЛІЗИНУ І МЕТІОНІНУ У КОМБІКОРМАХ}

\section{В. М. Кондратюк}

Анотація. Важливими чинниками, щео впливають на інтенсивність росту риби є дотримання оптимальних умов вирощування та повноцінно збалансованої годівлі. Раціональне використання поживних речовин комбікормів дозволяє отримати якісну товарну продукиію у короткі терміни. Гематологічні та біохімічні показники крові райдужної форелі мають важливе значення для оцінки якості годівлі.

Кров є чутливим та інформативним індикатором стану організму, швидко реагує на зміни як екзогенних, так $і$ ендогенних чинників. Динаміка біохімічних показників може слугувати маркером стану організму риб, характеризувати якість годівлі. Для характеристики загального стану організму дволітків райдужної форелі вагомими є біохімічні дослідження сироватки крові, щуо дають можливість отримати додаткові дані про фізіологічний стан риби. Білки крові регулюють колоїдно-осмотичний тиск $в$ організмі, підтримують рівновагу рН, виконують транспортну функиію. Білки плазми крові можуть слугувати резервом амінокислот.

Таким чином, вивчення питання впливу різного амінокислотного живлення товарної райдужної форелі на гематологічні та біохімічні показники $\epsilon$ необхідним для визначення потреби риби в лізині та метіоніні з метою забезпечення успішної діяльності холодноводних рибницьких господарств України.

Експериментальні дослідження на дволітках райдужної форелі Oncorhynchus mykiss (Walbaum, 1792) проведені в умовах господарства «Шипот» Перечинського району Закарпатської області.

Метою науково-господарського досліду передбачалося встановити вплив різних рівнів амінокислотного жсивлення товарної райдужної форелі на гематологічні та біохімічні показники їх крові.

Для изього за методом аналогів було сформовано п'ять піддослідних груп. У зрівняльний період піддослідна риба споживала комбікорм контрольної групи. В основний період досліду рівень лізину $і$ метіоніну у продукційному кормі коливався відповідно від 2,5 до 2,9\% і від 0,8 до 1,0\%.

Годівлю райдужної форелі в період досліджень проводили 4-6 раз на добу, в денний час через рівні проміжки. Необхідну кількість корму розраховували відповідно до показників індивідуальної маси риб та температури середовища на момент годівлі.

Зразки крові відбирали із серия за допомогою ін'єкційної голки, яку вводили із черевної сторони по сагітальній лінії між грудними плавиями. В якості антикоагулянта використовували гепарин.

Конщентрачію еритрочитів визначали пробірковим методом із використанням консервуючого розчину, мікроскопу і камери Горяєва, лейкоиити - непрямим методом на мазку крові, гемоглобін - гемоглобінціанідним методом 


\section{Кондратюк В. М.}

на спектрометрі. Окрім цุього, загальний білок у сироватці крові визначали рефрактометрично.

Показники пластичного обміну, а саме: вміст глюкози в крові риб визначали за методом I. П. Кондрахіна $i$ ін. Принциип методу заснований на здатності глюкозооксидази, окислюючись, утворювати комплексну сполуку, яка забарвлює розчин у рожевий колір. Інтенсивність забарвлення розчину пропориійна вмісту глюкози в пробі. Концентрацію глюкози в крові розраховували за стандартним розчином у ммоль/л. Вміст загального білку у плазмі крові риб визначали за допомогою наборів реактивів фірми «Lachema» (Чеська Республіка) та стандартних розчинів субстратів.

Результати досліджень опрацььовані методом варіаџійної статистики за допомогою програмного забезпечення STATISTICA 7.0. $i$ MS Excel 3 використанням вбудованих статистичних функиій.

Результати проведених гематологічних досліджень свідчать також про те, щуо різний вміст лізину та метіоніну в раціонах дволітків райдужної форелі не викликає суттєвих змін у морфологічному складі та біохімічних показниках крові.Разом з тим, виявлено, щуо у риб 2- та 3-ї оолідних груп дещуо підвишується вміст еритроцитів у крові від 1,21 Т/л до 1,25 Т/л, порівняно з аналогами контрольної групи.

Використання у годівлі піддослідних риб комбікормів із рівнем лізину та метіоніну відповідно 2,8 i $0,95 \%$ призводило до зменшення кількості еритроцитів у крові. Так, у крові форелі 4-ї дослідної групи він становив 1, 19 Т/л, щзо на 1,7-5,0\% менше порівняно з аналогічними показниками риб 2-ї та 3-ї дослідних груп.

Аналогічна закономірність спостерігалася $і$ за рівнем гемоглобіну у плазмі крові риб. Так, найвищий його вміст встановлено у плазмі крові форелі 4-ї дослідної групи. Зростання вмісту лімітуючих амінокислот у комбікормах молоді райдужної форелі викликало незначні відхилення за вмістом гемоглобіну, порівняно з контролем. Так, найнижчий рівень гемоглобіну (110 г/л) встановлено у крові риб 3-ї оослідної групи, в комбікормі яких рівень лізину становив 2, 6 \% та метіоніну - 0,85\%.

Нашими дослідженнями було також встановлено, щзо підвищення рівнів амінокислотного жсилення дволітків райдужної форелі суттєво не впливає на концентрацію лейкоцитів, хоча слід відзначити незначний позитивний вплив його на їх кількість у риб 4-ї та 5-ї дослідних груп.

Отже, використання в годівлі товарної райдужної форелі продукиійних комбікормів з різним вмістом лізину та метіоніну істотно не впливало на морфологічні показники крові.

Результати наших досліджень свідчать про те, щ⿻о різний рівень лімітуючих амінокислот (лізину та метіоніну) у раціонах дволітків райдужної форелі протягом періоду їхнього вирощування суттєво не позначається на біохімічному складі крові.

Концентрація загального білка в сироватизі крові була майже однаковою в усіх піддослідних групах товарної форелі. Однак відмічено, щзо зростання рівнів 
Кондратюк В. М.

лізину та метіоніну у комбікормах риб (4-а та 5-а дослідні групи) сприяло незначному зростанню вмісту загального білку у сироватці крові.

Підвищений вміст глюкози у крові риб 4-ї та 5-ї дослідних груп свідчить про активність обмінних процесів в організмі форелі, $і$ як наслідок - про збалансованість лімітуючих амінокислот у комбікормах. Найбільший ї̈ вміст (4,32 ммоль/л) був у крові форелі 4-ї дослідної групи, комбікорм яких містив 2,8 \% лізину та 0,95\% метіоніну.

Разом з тим, виявлено, щзо із зростанням рівня лізину та метіоніну в раџіоні райдужної форелі підвищується вміст глобулінів у крові риб до 39,1 г/л, порівняно з аналогами контрольної групи (37,8 г/л). Аналогічна закономірність спостерігалася $i$ за вмістом альбумінів у плазмі крові. Так, найвищий вміст альбумінів встановлено у плазмі крові риб 4-ї групи, які одержували повнораціонний комбікорм з підвищеним на 0,1\% лізину та 0,05\% метіоніну.

Отже, використання в годівлі райдужної форелі комбікормів з різним вмістом лізину та метіоніну істотно не впливало на морфологічні і біохімічні показники крові.

Аналогічна закономірність встановлена і за оцінки показників білої крові дволітків форелі. Зокрема, встановлено, що різні рівні амінокислотного живлення райдужної форелі не впливають на динаміку змін лейкоцитарної формули крові. Встановлено, щзо зростання рівнів лізину та метіоніну у комбікормах, які згодовували дволіткам, супроводжувало незначне збільшення кількості у їхній крові лейкоцитів, лімфочитів та моноцитів. Рівень загальних ліпідів при цьому, практично залишався без змін, $і$ становив у крові риб контрольної групи 4,3 ммоль/л, а у крові дослідних груп даний показник знаходився в межах 4,2-4,5 ммоль/л.

Ключові слова: товарна райдужна форель, годівля риб, комбікорми, лізин, метіонін, гематологічні показники, лейкочитарна формула, біохімічні показники $к р о в і$ 